International

Medical Society

http://imedicalsociety.org

\title{
Elaboration of an Educational Booklet about Papanicolaou Smear DofGCMal
}

Maria Gildellyana Maia de Moura1, Nadiny Veras Pereira1, Paula Mara Leal do Nascimento1, Demylson Sudario de Araújo', Natasha Marques Frota', Ana Carolina Maria Araújo Chagas Costa Lima1,

Camilla Pontes Bezerra1 , Bruna Michelle Belém Leite Brasil ${ }^{1}$, Samila Torquato Araújo1, Ana Priscila Marques Lima1, Lívia Moreira Barros², Joselany Áfio Caetano²

\section{Abstract}

Objective: To describe the process of building an educational booklet about Pap smear. Methods: Methodological study with a view to build an educational booklet about Pap smear. The construction of the booklet took place from September to October 2015 and took place in two stages: literature and manufacture of printed educational technology.

Results: The booklet entitled "Examination papanicolaou. Learn more!" was structured and contextualized with easy to understand information composed of 14 illustrative and informative pages in order to meet customer needs. The booklet is divided into ten areas that aim to clarify questions related to the Pap smear from the time before the exam to return to the researched result.

Conclusion: The booklet is a viable method for dissemination of knowledge, being able to contribute to the promotion of women's health as the Pap smear.

\section{Introduction}

Colo Uterus Cancer (CCU) has become an obvious public health problem, and in 2012, in Brazil, the third leading cause of cancer death in women. In 2014, it was estimated 15,590 new cases with a risk of 15.3 cases per 100,000 women, and this year the fourth leading cause of death in women from cancer and the third most common tumor in this population. In the Northeast of Brazil, it is the second most frequent with 18.79 / 100,000 per capita [1].
1 Department of Nursing, Centro Universitário Estácio. Fortaleza, Brazil.

2 Department of Nursing, University Federal of Ceará. Fortaleza, Brazil.

Contact information:

Natasha Marques Frota.

Address: Rua Eliseu Uchôa Beco, 600, Água Fria, Fortaleza, CE, Brazil, 60810270.

Tel: +055(85)3267-1892

झ natashafrota_@hotmail.com

Keywords

Nursing; Papanicolaou Test; Women's Health; Nursing Education. 
Cervical alterations caused by one or more of the oncogenic types of Human Papilloma Virus (HPV) are the main risk factors for the onset of cervical cancer. HPV is a viral disease transmitted more often at intercourse, which affects men and women, can be installed either in the mucosa and skin. There are over 100 types of HPV in the world, with about $70 \%$ of cases of cervical cancer are caused by types 16 and 18. The impact of HPV has significant record in Brazil with nearly 700,000 new cases per year. Thus, HPV infection is a necessary factor but not sufficient for development of cervical cancer [2].

The tracking programs aimed at regular Pap smear testing that are considered strategic, however the lack of information of women about the importance of the examination and the early diagnosis results in a significant rate of incidence and mortality from cervical cancer [1].

The early detection of cervical cancer is the clarification of the population on the Pap smear, the identification of women at increased risk, the procedures of cytological collecting, during the identification of women with positive results, and the importance of highlighting the return of these women to seek the clinical report [3].

Regarding the CCU, one study showed that women show interest in promoting their health and that despite not having the proper knowledge, have convenient attitudes, as the Pap smear is engaged as a strategy for reducing the incidence of morbidities [4].

In this sense, the nurse has an essential role in controlling the CCU, since the fulfillment of educational activities help raise awareness among women about the importance of conducting the Pap smear and the different aspects related to prevention. Thus, it seeks to adopt practices and behaviors consistent with a healthier life [2].

Therefore, the nurse can act in order to promote health in the use of educational technologies that seek empowerment for women, based on the cla- rification and support for them to assume greater control over their health and their life. Based on this premise, health education is incorporated as a nursing intervention instrument in monitoring the CCU. The use of educational materials facilitates understanding and makes available the appropriate knowledge to the female population.

In the health area, the educational process is constantly changing with the use of innovative educational materials that are able to promote understanding, showing the positive impact on the maintenance of self-care. Educational materials such as brochures, booklets and health care manuals are examples of devices that provide access to information. Based on this premise the Unified Health System (SUS) prepares materials to contribute to the empowerment of people with their health [5].

Based on this context, it is noticeable that nursing education is a primary tool of knowledge to the population. Because of this, it is justified the need to create an instrument with a higher content of information on the implementation of Pap smear. This study is relevant as it may favor the encouragement of women to carry out the gynecological from this clarification and encouraging for the search result. So, we have the objective to describe the process of building an educational booklet about Pap smear.

\section{Methods}

This is a methodological research, which focuses the development, evaluation and improvement of an instrument or strategy that can improve a methodology. In this study, an educational booklet was developed on the Pap smear, and adopted the methodology proposed by Echer [6], which explains about the stages of the construction process of teaching materials for health care. It was used two steps to this study: literature review and preparation of educational materials. 
The booklet construction process occurred in the period from September to October 2015, in which a search in major publications of the Ministry of Health of Brazil about the care and guidance on the Pap smear was performed, as well as scientific articles to submit validation and clarity in its publication.

The literature was given through the use of tools of databases: Scientific Electronic Library Online (Scielo); MEDLINE (Medical Literature Analysis and Retrieval Sistem online); Science Direct; and LILACS (Latin American and Caribbean Health Sciences). The search these databases aimed to broaden the scope of research and minimize potential biases. We used the crossing of descriptors "Pap Test / Pap Test", "Educational technology / Educational Technology", "Education in Nursing / Education Nursing", taken from the descriptor in Health Sciences (DECS) of the portal of the Virtual Health Library (BVS).

The inclusion criteria were: articles in full, in English, Spanish and Portuguese, with publication in the period 2010-2015 and related to the Pap smear. On the other hand, the exclusion criteria were: research related to reviews, dissertations and theses. For the selection of studies, first, we proceeded to read the title and summary for prior review and confirmation that the manuscript contemplated information on the subject under study. It is noteworthy that, in the event of questions about the article content and whether it met the inclusion or exclusion criteria, it was decided to include it in the sample.

Later, it was made a careful reading of the 34 articles in full, in order to identify key ideas and guidelines directed to the object of study, which gave a final sample of 18 articles.

The built booklet was entitled "Examination Papanicolaou. Learn More! ", Addressing in its content the care and guidance on the Pap smear.

To manufacture the material was counted with the support of a professional graphic designer in the area to perform the technical part of the playbook. The programs used for making the graphics were Corel Draw Essentials to design and Adobe Photoshop to color the figures. As the booklet was taking shape and structure the researchers were suggesting necessary changes. The layout and configuration occurred through Adobe Indesign program.

The initial content of the booklet consists of attractive elements with introductory approach theme aimed to encourage reading educational material. Then the booklet addresses on the clarification of what the Pap smear, how and where is its implementation, benefits, target audience and professionals who perform it, with illustrations and captions, as well as relevant questions for the exam.

They were avoided technical and scientific terms, abbreviations and acronyms, but when it was necessary to use them have been properly explained their definitions. Whenever possible, they used simple words, easy to understand, short and very extensive sentences, each theme developed completely on the same page to then approach the next subject. The final part of the booklet is focused on the notes queries prevention, and provided a table for monitoring the queries and returns to the office.

It was used illustrations to help explain and/or emphasize important points and ideas of the text, and avoided abstract illustrations and had only decorative function. The illustrations sought falls within the social context of the target audience without juvenile aspect, with good quality and high definition. The illustrations were arranged easily for the reader to follow them and understand them, next to the texts to which they refer, seeking to meet its goal of being self-explanatory.

The booklet layout had its source with number 16 , as the material intended for adult audiences, being the source of the title two points higher than the text. Not used stylized fonts by obstructing the reading [1]. 
The colors were used with sensitivity and caution not to supercolor the booklet/primer, which would visually polluted, and the printing of black letters on light background easier to read. The print used was dull (paper and ink), it reduces glare and improves readability.

\section{Results}

A booklet entitled "Examination Papanicolaou. Learn more! "Was contextualized with easy to understand information composed of 14 illustrated and informative pages in order to adequately meet the customer needs.

The information contained in the booklet aim to clarify questions relating to the pap smear from the time before the exam to return to the search result as well as the gynecological screening.

After the initial presentation of the booklet, women have access to other information, organized in areas, which are divided into ten: 1. Presentation of the booklet; 2. Presentation of Especulino character; 3 . What is the Papanicolaou examination and serving?; 4. Where can I take the examination?; 5. What women should take the examination?; 6. What professional can accomplish it?; 7. What should I watch before taking the exam?; 8. Materials used for testing; 9. When should I return to take the exam?; 10. How long should I return to repeat the exam? (Table 1).

In Figure 1 you can observe the cover of the booklet.

Below in Figure 2, there is the presentation of "Especulino" interactive educational object created to dialogue with women throughout the booklet.

Regarding the examination itself, figure $\mathbf{3}$ makes an initial presentation of the Papanicolaou test, in order to display the remaining steps.

For this booklet we used an idea at a time, with actions in a logical order, including only the infor-

Table 1. Description of the contents by areas of the booklet.

\begin{tabular}{|c|c|}
\hline Domains & Contents \\
\hline Presentation & $\begin{array}{l}\text { Discussed the factors related to incidence and relevance of the CCU in women in Brazil, which was } \\
\text { presented to infection by the HPV virus as a major causal risk factor, and addressing the Pap test as a } \\
\text { means of detection. }\end{array}$ \\
\hline "Especulino" & $\begin{array}{l}\text { "Especulino" consists of a tool that strengthens the transmission of knowledge in accordance with the } \\
\text { characteristics of the target audience. This avatar constitutes a dynamic tool in order to propitiate an } \\
\text { attractive communication readers. }\end{array}$ \\
\hline Papanicolau exam & $\begin{array}{l}\text { Domain } 3 \text { presents an explanation of what the Pap smear and explains his injuries identification } \\
\text { function and prevention of cervical cancer. }\end{array}$ \\
\hline $\begin{array}{l}\text { The examination } \\
\text { venue and women } \\
\text { that should do }\end{array}$ & $\begin{array}{l}\text { Pap smear can be done in the Basic Health Unit. It should be done by women who began their sexual } \\
\text { life to } 64 \text { years and pregnant women. }\end{array}$ \\
\hline $\begin{array}{l}\text { professional } \\
\text { responsibility and } \\
\text { care }\end{array}$ & $\begin{array}{l}\text { As for the professional responsible for performing in the area } 6 \text {, it is explained that the nurse health } \\
\text { professional or physician is qualified to perform the exam. The care provided by women before } \\
\text { performing the examination are listed and presented in the form of illustrative figures to become more } \\
\text { dynamic and facilitating comprehension and understanding (domain 7). }\end{array}$ \\
\hline Material used & $\begin{array}{l}\text { With regard to the material used in the examination, aimed to inform the basic materials for the } \\
\text { realization of cytological collection, and illustrate the gynecological position as area } 8 \text { of the booklet. }\end{array}$ \\
\hline $\begin{array}{l}\text { Return to take the } \\
\text { exam }\end{array}$ & $\begin{array}{l}\text { Domains } 9 \text { and 10, refer to the return of the patient to take the exam and the time to repeat } \\
\text { respectively. In these areas women are targeted clearly and objectively the importance of seeking the } \\
\text { examination of the recommendations provided by the trader in return visits and are encouraged and } \\
\text { educated when performing the exam itself. }\end{array}$ \\
\hline
\end{tabular}


Figure 1: Booklet's cover: Papanicolaou smear. Learn more!.

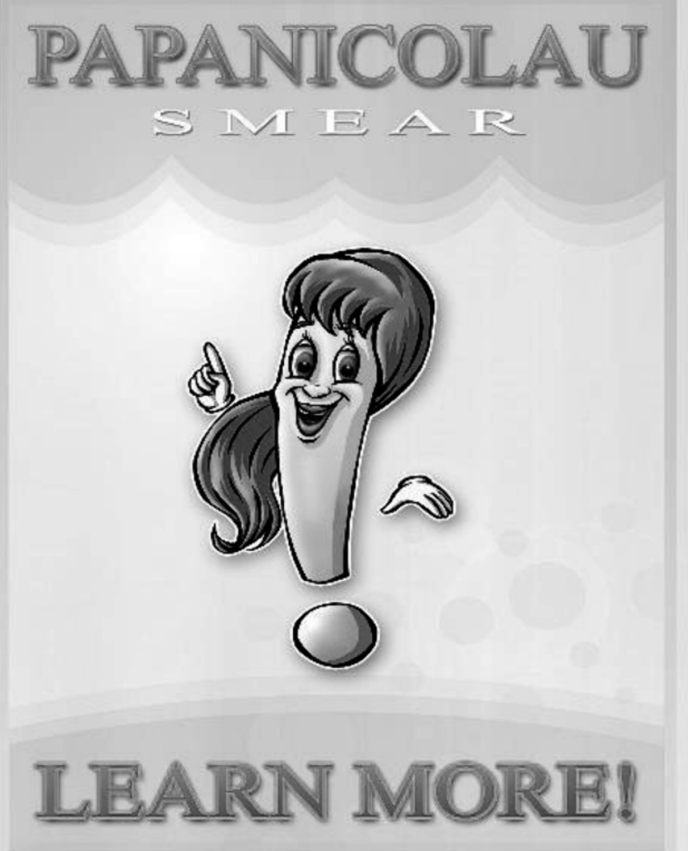

Figure 2: Educational Object Image, "Especulino".

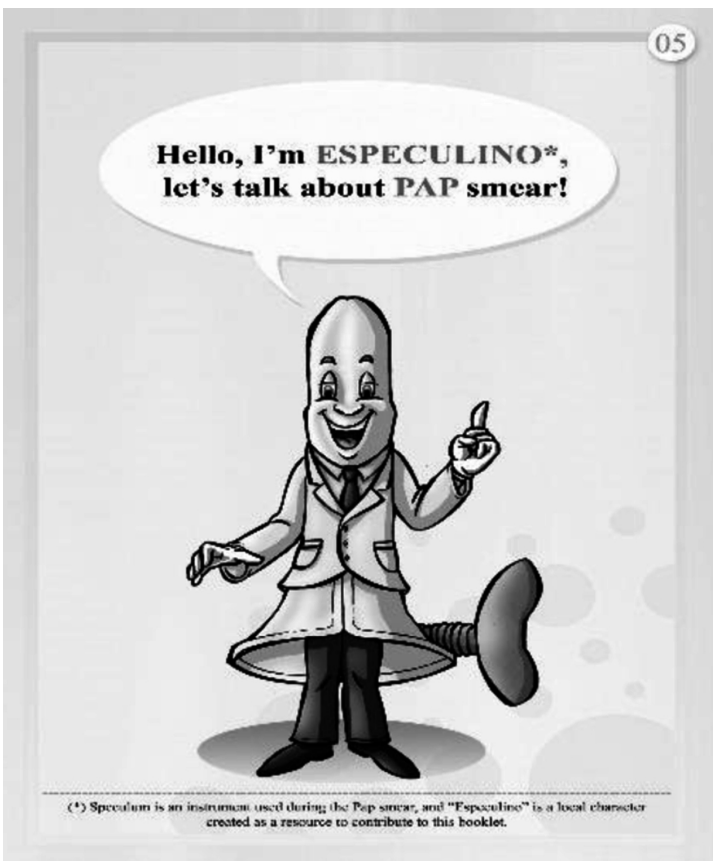

Figure 3: What is the Pap smear and serving?

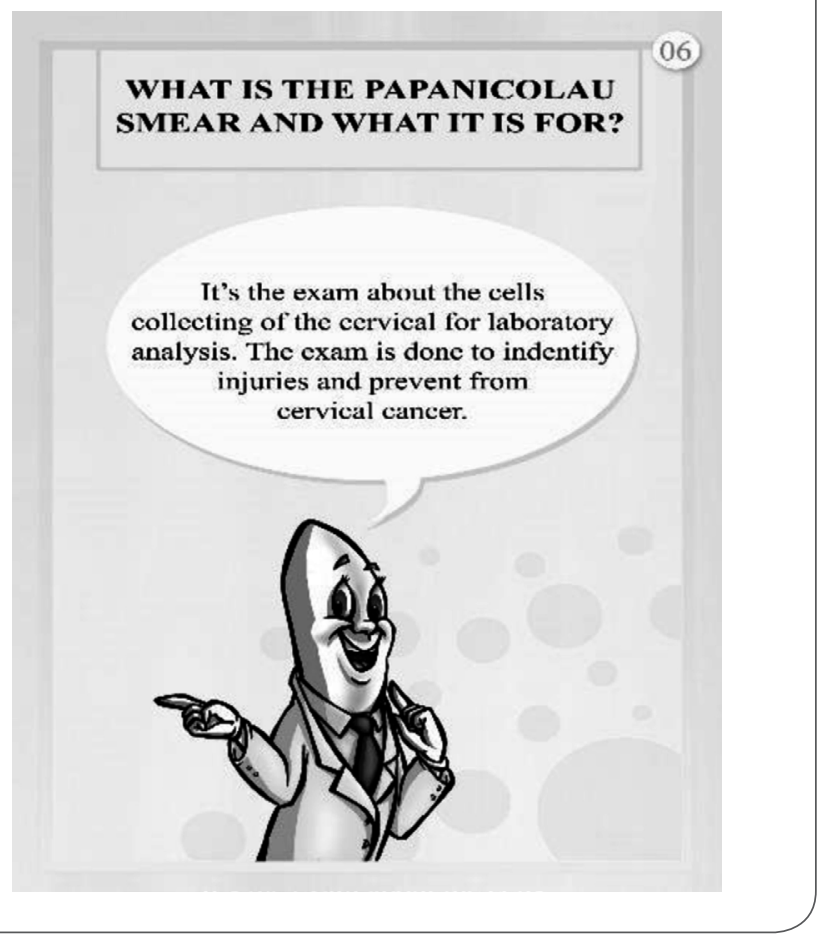

mation necessary for the perception of the reader through short sentences avoiding technical terms and jargons of uses.

We also opted for a style that makes it easy to read and understand. Simple line drawings were selected to facilitate the understanding and interest of the reader as well as color and attractive text, which allows the reader to capture the message for illustration, because for many people the illustrations are able to explain better than reading.

\section{Discussion}

Health education in nursing is shown as an important means of spreading information concerning the improvement of quality of life (QoL) and health promotion for the population. In such a context have are educational technologies that contribute as support tools for these nursing actions, as well as providing the reduction of difficulties in practice of nurses are also able to promote the empowerment of health by the target audience with possible changes behavioral. 
Teaching materials act as facilitators tools for educational practice, because the shortage of physical resources, human, structural and materials, make dull and unexciting learning. So this shows a greater feasibility of using educational technology as a facilitator feature in education [7].

The use of educational materials must meet the needs of the reader, offering a language easy to understand, allowing you to an understanding of the content addressed [5].

The use of educational technology for nursing collaborate in their individual and collective assistance whatever environmental development actions, but the construction of educational material, or even the use of existing materials is needed for education strategies health, where to ensure effectiveness and validity, it is proper to evaluate these [8].

In a study brokered by a flipchart on self-efficacy about breastfeeding showed evidence of behavioral changes favorable guided in the educational technology contribution to increased confidence in achieving consistent customary actions to the promotion of their health. It was stated that the educational intervention promotes a positive response and that the use of flipchart is recommended for support programs [9].

In a different study, the relevance of the construction and use of educational material on healthy eating with regional foods during pregnancy, and a booklet resource for nursing education. In this study, the audience evaluated the material in their motivational aspects for reading, like content writing and illustrations [10].

The use of digital learning objects can also be a tool that favors interaction with the reader. In a study that used an educational hypermedia on peripheral venipuncture, told with educational object named "Scalpelito", as an auxiliary tool for improving knowledge, favoring interaction and dynamics in the learning process [11].

Given the proposal to develop educational materials, it is clear that support health education through educational technology favors the dissemination of information, contributing to the practice of nursing, teaching and learning. As the nurse a component of the educational process of the individual, favoring their understanding about the empowerment of their state of health and risk behaviors.

Each person is responsible for furthering your education in health, thus the educational materials come as an information tool capable to north it on your self-care, making it autonomous for the promotion of health. Disclosure of information on the subject should enable the understanding of woman in order that it be able to absorb the transferred knowledge, practicing attitudes that enable a better quality of life with disease prevention and health promotion [1].

The development of educational materials focused on women's health contributes to providing the control of high levels of CCU. The creation and use of consultation tool the woman applied in the waiting room for the screening test shows to be effective which provides comprehensive care and providing opportunities for dialogue with exchange of knowledge among women, and pass comprehensive information on the screening test and breast [12].

In this scenario in health care, the use of educational materials in particular a primer as part of women's health, seeks to disseminate relevant information on the theme of the Pap smear, as well as prevention and early or detect factors that may are linked to CCU, and clarify possible doubts present in the everyday woman.

\section{Conclusion}

The construction of the booklet intends to expand the knowledge of women through the application of instructional material. The use of educational technology becomes attractive, which leads to dynamic and differentiated learning by the target audience. 
The nurse is active in professional care and education, thus being responsible for the dissemination of knowledge to the community and able to contribute to the development of skills and self-care by individuals. Therefore, the primer can be a method used as a tool for health education.

We considered this valuable study to better understand the ability of nurses in the development and operation of educational technologies in the health scenario of women, bringing an educational material in order to contribute to the professionals who are part in providing assistance as also for women who have the benefit of information, enabling them and empowering them to perform the Pap smear.

This study has the limitation has not been submitted to the validation process to experts, but it is expected that at an opportune time to accomplish it, and with the target audience in order to carry out necessary adjustments and updates through scientific advancement and technology.

\section{References}

1. Moreira CB, Bernardo EBR, Catunda HLO, Aquino OS, Santos $\mathrm{MCL}$, Fernandes AFC. Construção de um vídeo educativo sobre detecção precoce do câncer de mama. Rev Bras Cancerol. [Internet] 2013 [cited 2015 nov 07]; 3:401-7. Available from: http://www1.inca.gov.br/rbc/n 59/v03/pdf/10-artigoconstrucao-video-educativo-sobre-deteccao-precoce-cancermama.pdf

2. Moura ADA, Silva SMG, Farias LM, Feitoza AR. Conhecimento e motivações das mulheres acerca do exame de papanicolaou: subsídios para a prática de enfermagem. Rev Rene [Internet] 2010 [cited 2016 jan 09]; 11:94-104. Available from: http://www. revistarene.ufc.br/revista/index.php/revista/article/viewFile/365/ pdf

3. Vasconcelos CTM, Damasceno MMC, Lima FET, Pinheiro AKB. Integrative review of the nursing interventions used for the early detection of cervical uterine cancer. Rev Latino-am Enfermagem. [Internet] 2011 [cited 2016 jan 09]; 19:437-44. Available from: http://www.scielo.br/pdf/rlae/v19n2/28.pdf

4. Ribeiro KFC, Moura MSS, Brandão RGC, Nicolau AIO, Aquino PS, Pinheiro AKB. Student nurses' knowledge, attitude and practice regarding the papanicolaou examination. Texto Contexto Enferm. [Internet] 2013 [cited 2015 dec 10]; 22:460-67. Available from: http://www.scielo.br/pdf/tce/v22n2/en v22n2a23.pdf
5. Reberte LM, Hoga LAK, Gomes ALZ. Process of construction of an educational booklet for health promotion of pregnant women. Rev Latino-am Enfermagem. [Internet] 2012 [cited 2015 dec 10]; 20:101-8. Availabe from: http://www.scielo.br/pdf/rlae/ v20n1/14.pdf

6. Echer IC. Elaboração de manuais de orientação para o cuidado em saúde. Rev Latino-Am Enferm. [Internet] 2005 [cited 2016 jan 11]; 13:754-7. Available from: http://www.scielo.br/pdf/rlae/ v13n5/v13n5a22.pdf

7. Fonseca LMM, Leite AM, Mello DF, Silva MAI, Lima RAG, Scochi CGS. Tecnologia educacional em saúde: contribuições para a enfermagem pediátrica e neonatal. Esc Anna Nery. [Internet] 2011 [cited 2015 nov 13]; 15:190-6. Available from: http://www. scielo.br/pdf/ean/v15n1/27.pdf

8. Oliveira PMP, Pagliuca LMF. Assessment of an educational technology in the string literature about breastfeeding. Rev Esc Enferm USP. [Internet] 2013 [cited 2015 nov 13]; 47:20512. Available from: http://www.scielo.br/pdf/reeusp/v47n1/en a26v47n1.pdf

9. Dodt RCM, Ferreira AMV, Nascimento LA, Macêdo AC, Joventino ES, Ximenes LB. Influence of health education strategy mediated by a self-efficacy breastfeeding serial album. Texto Contexto Enferm. [Internet] 2013 [cited 2015 nov 13]; 22:610-18. Available from: http://www.scielo.br/pdf/tce/v22n3/en_v22n3a06.pdf

10. Oliveira FLB, Araújo DV, Meneses RMV. Report on the construction of an instrument of consultation to woman. Rev Enferm UFPE on line [Internet] 2014 [cited 2016 jan 11]; 6:1807-13. Available from: http://www.revista.ufpe.br/revistaenfermagem/ index.php/revista/article/view/4851/pdf 5379

11. Frota NM, Barros LM, Araújo TM, Caldini LN, Nascimento JC, Caetano JA. Construction of an educational technology for teaching about nursing on peripheral venipuncture. Rev Gaúcha Enferm. [Internet] 2013 [cited 2015 nov 13]; 22:610-18. Available from: http://www.scielo.br/pdf/rgenf/v34n2/v34n2a04.pdf

12. Oliveira SC, Lopes MVO, Fernandes AFC. Development and validation of an educational booklet for healthy eating during pregnancy. Rev Latino-am Enfermagem. [Internet] 2014 [cited 2015 nov 13]; 22:611-20. Available from: http://www.revistas. usp.br/rlae/article/view/86672/89669

Publish in International Archives of Medicine

International Archives of Medicine is an open access journal publishing articles encompassing all aspects of medical science and clinical practice. IAM is considered a megajournal with independent sections on all areas of medicine. IAM is a really international journal with authors and board members from all around the world. The journal is widely indexed and classified Q1 in category Medicine. 